\title{
RESEARCH STUDIES ON BIO-ECONOMIC DEVELOPMENT OF BANAT REGION: TRADITIONS, ACTUALITIES, PERSPECTIVES.
}

\author{
Matiuti Marcel $^{1 *}$, Diaconescu Denis Laurentiu², Hutu Ioan ${ }^{1}$, \\ Matiuti Carmen-Luminita ${ }^{3}$ \\ ${ }^{1}$ Faculty of Veterinary Medicine, Calea Aradului 119, Timisoara, Romania \\ ${ }^{2}$ GNIR Bucharest, Romania \\ ${ }^{3}$ Technicall College Azur Timisoara, Romania \\ *correspondence to: matiutimarcel@yahoo.com
}

\begin{abstract}
This scientific paper advances a possible solution for the creation of a Biocultural Protocol for the rural communities of Banat region maintaining or reviving rural vivacity. By traditions point a view the local breeds are part of the Cultural Intelligence of rural communities in Romania. They show the intelligence, work and creativity of the people of this communities. Preserving local breeds means respect for the community that created them and for the work involved in this process. Actually, the Transilvanian Rare Breeds Association offers constantly through Consultancy but also by University extension, support those local livestock breeds giving them solutions for their preservation and maintaining their motivation. Ethnozootecny studies the relation between man-animal-environment in past and present societies and their transformations determined by animal breeding evolution. Ethnozootechny gathers elements of comparison, reflexion and useful information for those who are interested in history and in the future of animal breeding. The destruction of the zoogenetic biodiversity means destroying a lifestyle, a civilisation. Genetic diversity is a basis for food security and rural development. Ethnogastronomy have a large number of recipes. Products made from recipes are verified over the course of time. Each community in Banat borrowed from one another what was best. It is important for Banat bioeconomy to facilitate the rapid implementation of technical and technological innovations such as eco, nature-friendly technologies. One example for bioeconomic competitiveness is the rural pole of local development - several projects intentions are ongoing. In the perspective, the Banat should have the Resilience force, meaning the ability to resist bio-economically or economically through the multitude of existing knowledge. The territorial capital of Banat Euroregion is not enough known. When a territorial capital will be established, correct decisions can be made and the territorial economic intelligence may be determined.
\end{abstract}

Keywords: ethnozootehny, biodiversity, cultural intelligence, Biocultural Protocol

\section{Introduction}

This scientific paper advances a possible solution for the creation of a Biocultural Protocol for the rural communities of Banat region maintaining or reviving rural vivacity.
The landscape of Banat represents the modeling work started in the 18th century, when ample hydroelectric works and marshlands drainings were started in order to make farmland. "The citizens of Banat were 
people with education, with respect for the work and the property of others" [1]. "Economic intelligence promotes solutions for maintaining domestic biodiversity by providing tools necessary for obtaining the information that allows farmers to anticipate and defend their economic interests" [2].

\section{Materials and Methods}

Actually, the Transilvanian Rare Breeds Association offers constantly through Consultancy but also by University extension, support those local livestock breeds giving them solutions for their preservation and maintaining their motivation.

Throughout the years at conferences and symposiums in the country and abroad, we presented the creation of local communities in Banat and Transylvania in the field of animal husbandry, promoting the local breeds (their creation), their monitoring and the ways of protecting the national zoological patrimony. These works have been published in prestigious journals [3 - 13]. Much of the information is from the Transilvanian Rare Breeds Database.

The study implies the approach of various subjects, methods and intentions from the point of view of a SWOT analysis.

\section{Results and discusion}

Scheme 1 shows the proposed strategy for maintaining zoogenetic diversity in the Euroregion Banat for the period 2016-2030. This strategy is in line with the Bioeconomy development strategy for the period 20142030 developed by the European Union. The scheme is also based on the work of two researchers from France [14].

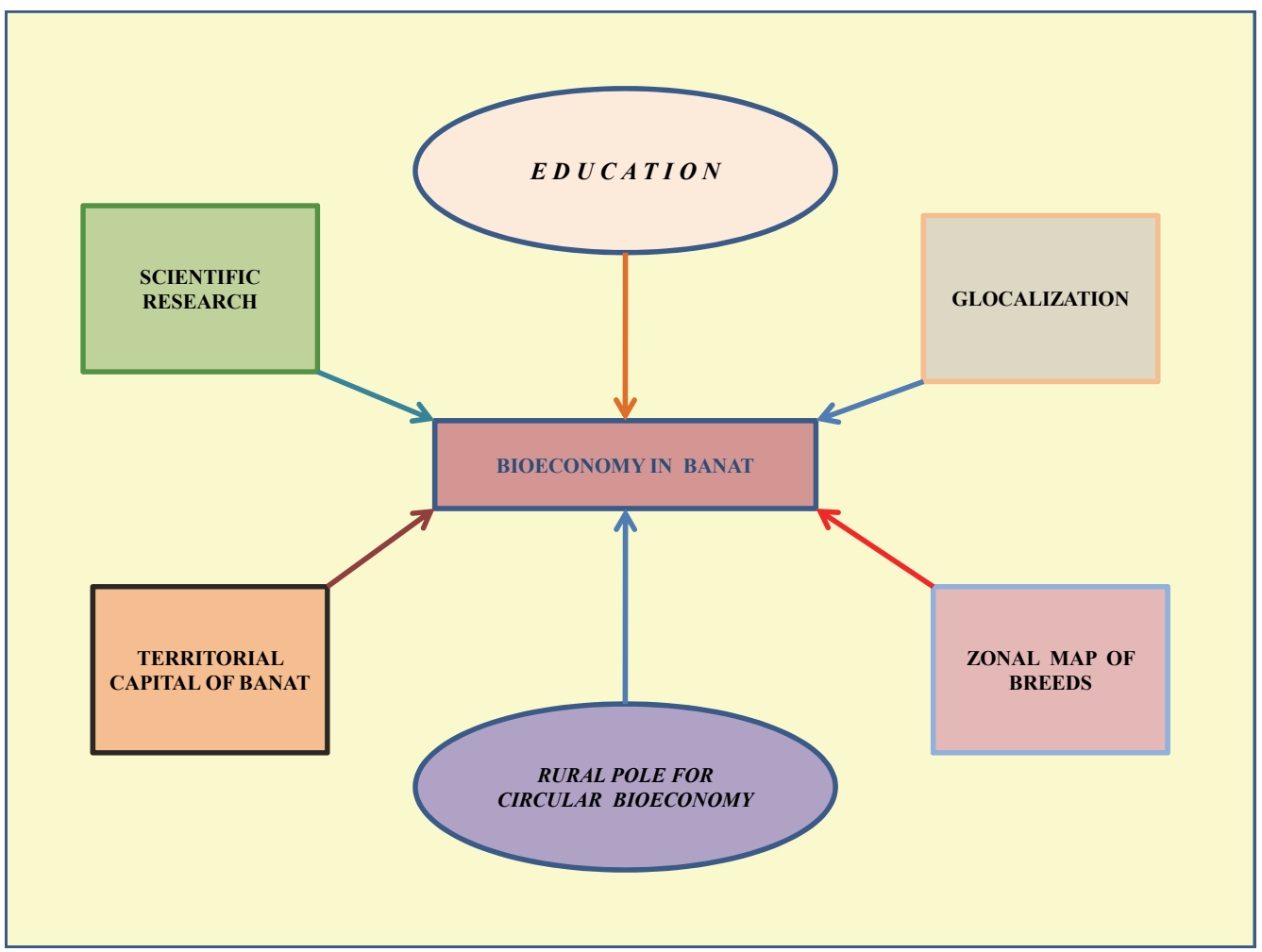

Fig. 1. The pillars for raising economic competitiveness in Banat 
Table 1. SWOT analysis for Romanin Banat in zootechny development

\begin{tabular}{|l|}
\hline Strenghts \\
\hline - geographic location \\
- the existence of infrastructure necessary \\
for economic activity \\
- cooperation between local producers and \\
agri-food industry \\
- institutions for education \\
- tradition in animal breeding \\
- the modern technology applied in \\
zootechny \\
- pedological dibersity \\
- existence of land register \\
- existence of Danube River the central \\
axis which links Romanian Banat with \\
Central and West Europe \\
\hline Weaknesses \\
\hline lack of knowledge of the territorial capital \\
- lack of industry with environment- \\
friendly technology \\
- low quality of management \\
- insufficient agricultural roads- old \\
agricultural machines and high price for \\
the new technology \\
- the continuous decrease of the number of \\
animals \\
- bureaucracy \\
-bad strategy and tactics in granting grants \\
- population of the plain areas with sheep \\
- detrimental to productive species (pig, \\
poultry, dairy cows) \\
- lack of map zoning of breeds / of support \\
in breeding zonation \\
\hline Opportunitis \\
\hline
\end{tabular}

\section{Opportunities}

- excellent pastures for livestock

- the possibility to access European funds

- the identification of a niche market

- the potential to increase the animal

product market

- crossborder cooperation

- the existence of diversified

ethnogastronomy

- the application of a bio-economic EU

strategy for development in 2030-2050

- the relatively small distance to airports

and ports on the Adriatic See

- glocalization

\section{Threats}

- climate change

- erosion of the domestic biodiversity
- the excessive fiscality

- the instability of legislation

- lack of rural webnetwork

- the migration of people from the

countryside

- globalization

From SWOT analysis of opportunity in the zootechny development in Romanian Banat is presented in following table (Tabel 1). The SWOT analysis also has its limitations, as organizations may see some circumstances as being very simple and may overlook some of the fundamental strategic contacts that may arise. Moreover, categorizing issues as strengths, weaknesses, opportunities and threats could be very subjective as there is a high degree of uncertainty in the market.

\section{History and tradition in technology}

Ethnozootechny studies the relation between man-animal-environment in past and present societies and their transformations determined by animal breeding evolution. Ethnozootechny gathers elements of comparison, reflexion and useful information for those who are interested in history and in the future of animal breeding. "Ethnozootecny studies the relation between man-animalenvironment in past and present societies and their transformations determined by animal breeding evolution "14].

"For all the Banat areas the dwelling is characteristic" [15]. This is basically the equivalent of the American ranch. If a comparison is made between the nineteenthcentury and the 2018-type of dwellings, there is a great resemblance. The house was built in the middle of the land owned by the family and was made up of a dwelling for the people and separately the shelters for the animals, for the agricultural machinery and tools and the room for the preparation of the products. Most of the lodges were equipped with a brandy boiler. The existence of the dwellings makes the work of the field easier, representing a form of integration of plant culture and animal breeding. Breeding animals at a dwelling also had the role of isolating them from epizootics. Including for people, it was the place of refuge in the case of plague. Ethnozootechny gathers elements of comparison, reflexion and useful 
information for those who are interested in history and in the future of animal breeding. "The destruction of the zoogenetic biodiversity means destroying a lifestyle, a civilisation" [2]. Genetic diversity is a basis for food security and rural development.

"By traditions point a view the local animals breeds are part of the Cultural Intelligence of rural communities in Romania" [16]. They show the intelligence, work and creativity of the people of this communities. "Preserving local animals breeds means respect for the community that created them and for the work involved in this process" [17].

\section{Diversified ethnogastronomy and rural economy/turism:}

Ethnogastronomy have a large number of recipes. Products made from recipes are verified over the course of time. Each community in Banat borrowed from one another what was best. The knowledge acquired by each ethnic community of Banat represents sample of the material life of different generations. Much of ethnogastronomy of Banat has been lost because the recipes used to be transmitted orally from generation to generation or through grandmother's notebook from the drawer of the kitchen cupboard. There is the possibility of organizing tourist routes on the "map" Banat following places with different traditional dishes, associated with various hiking that highlight the picturesque Banat.

"Marketing products from local breeds has two advantages: traditional technical processing - production or manufacturing clothing with a characteristic design" [16].

\section{Bioeconomy and rural pole development and circular economy}

It is important for Banat bioeconomy to facilitate the rapid implementation of technical and technological innovations such as eco, nature-friendly technologies. One example for bioeconomic competitiveness is the rural pole of local development - several projects intentions are ongoing. National Group of Professional Initiative for applied Bioeconomics in Romania (GNIBA) is promoting a complex sustainable rural development project that brings together a large number of business opportunities in Romania and other countries.

The project "Pilot Project for Integrateg Park based on Bioeconomy" is based on current conditions in Romania and offers state-of-the-art solutions to the stringent problems facing the rural communities. In so doing, it puts in place the first bases for the poles of competitiveness in rural Romania, where the vegetal and animal production as well as that of their derivatives benefit from very good geo-climatic conditions and are supported by traditions, relevant schools and others. "Implementing the project will not only spell a new dimension for the rural economy and society, but also provide jobs with the rural agro-industrial park, the business centre and the units processing vegetal and animal raw materials" [18], [19].

The project equally contributes to increasing the incomes of the local authorities as it offers a chance to diminish the effort represented by aid provided to the pauper and the socially-assisted, and by developing the business travel, consequently by increasing the national and international visibility of the area in question.

The multi-purpose areas in the park allow for creating banking, sanitary, veterinary and educational units in the rural world. There continuous learning can be done to continue crafts specific to the respective area; an entrepreneurial, associative and competitive spirit can be created while different pieces of equipment, technologies, valuable breeds and strains are presented to the farmers. It is again here that a trade area or the sale of household appliances will be developed.

Interested companies and people in the food industry may become involved into processing vegetal raw materials into daily food, bakery, pastry and sweets, as well as in breeding and processing poultry, pigs, goats, sheep and cattle in areas close to the park. The project may also generate a profit for the manufacturers of equipment for use in slaughter houses, meat-processing units, the diary industry, in processing fruit and vegetables. Important progress in circular economy and knowledge-based bioeconomy is evident in recent years. Numerous new processes and technologies have been 
developed and are at different TRL stages. An example in this respect is the new invention called" Process for biorefining of sugar yielding plants with conservation and extraction of sugars to produce biofuels and other bioproducts" developed by Inventor: Dr. Vintilă Teodor, biotech engineer at USAMVB' King Michael Ist of Romania from Timișoara. The Patent Application is registered to Romanian Office for Inventions and Marks. „This invention brings an extremely important novelty, namely: treating lignocellulosic biomass by original patented process has better effect in terms of improving access of enzymes for hydrolysis of cellulose than conventional methods of thermalchemical pretreatment (alkaline/steam)" [20]. The treatment of biomass according to patenting process has triple effect: (1) preservation of sugars, (2) extraction of sugars and (3) release of cellulose from lignocellulosic complex and access of cellulolytic enzymes to hydrolyse cellulose to glucose. Recently, at the world event "Climate Launchpad" - the world's largest green business ideas competition, the invention reached the world semifinal and won the Ist place at national Climate Launchpad final in Romania [21].

\section{Conclusions}

In the perspective, the Banat should have the Resilience force, meaning the ability to resist bio-economically or economically through the multitude of existing knowledge. The territorial capital of Banat Euroregion is not enough known. "When a territorial capital will be established, correct decisions can be made and the territorial economic intelligence may be determined "[22].

Based on all these analyzes and information, a Biocultural Protocol of Banat could be created.

\section{References}

[1] Popovici, Gh., Banatul Montan. Ghid turistic., Ed. TIM Resita (2011)

[2] Digard, J. P., L'homme et les animaux domestiques, Ed. Fayard, Paris (2009)

[3] Matiuți, M., Crăiniceanu E., Research regarding native domesticated endangered animal breed, USAMVB Timisoara Fac. de
Zootehnie şi Biotehnologii 29-30 mai, 41 (1), 221-224 (2008)

[4] DataBase of Association Transivanian Rare Breeds

[5] Matiuți, M., Bogdan, A. T., Matiuți, C. L., Adaptation to the Environment of Rustic Animal Breeds in Banat with Eco-economic Impact, Zilele Academice Arădene Univ. de Vest „Vasile Goldiş” mai Arad Seria Științe Economice Fascicula 21/2011 ( II), 22-29 (2011)

[6] Matiuți, M., Matiuți Carmen-Luminița, The Necessity of Gene Bank in Order to Protect the Breeds created on Romanian Territory, The 35-th ARA 26-31 July, Timisoara, Proceedings American Romanian Academy of Arts and Sciences, ISBN 978-2553-01596-0, România ISBN 978-1-93592401-2, 129-132 (2011)

[7] Matiuți, M., Methodology for the Elaboration of Sectorial Studies for Territorial Capital by Synergy of the sequential components based on Eco-BioeEconomy with a view to form the rural Web Network of zoogenetic Biodiversity in the Banat region, Danubius Journal of Regional Cooperation Belgrad, bilingv, sept internet (2012)

[8] Matiuți, M., Bogdan A. T., Matiuți, C. L., The importance of the local breeds poultry for genetic industry in aviculture, Bulletin of UASVM Cluj -Napoca Animal Science and Biotehnologies, 69 (1-2) /2012, 69 (2012)

[9] Matiuți, M., Bogdan, A. T., Matiuţi, C. L., The Ethnozootechnical solution for preservation and development of zoogenetic heritage in Romania and in Europe, Bulletin of UASVM Cluj -Napoca Animal Science and Biotehnologies, 69 (1-2) /2012, 136143(2012)

[10] Matiuti, M., Bogdan, A. T., Matiuti, C. L., Valorization of the zootechnical potential within the territorial capital of Banat, through eco-bio-geo-economic strategy, Bulletin of UASVM Cluj -Napoca Animal Science and Biotehnologies, 70(1) /2013, 65-78 (2013)

[11] Matiuti, M., Bogdan A. T., Matiuti, C. L., The new concept of eco-bioeconomy in the elaboration of strategies for safety food and defense food, Danubius Journal of Regional Cooperation Belgrad, bilingv, ian internet (2013)

[12] Matiuti, M., Bogdan, A. T., Matiuti, C., 
The Application of an Eco-Innovative Concept for Creating an Integrative Gene Banks in Animal Science and Production, Bulletin UASMV Cluj-Napoca Animal Science and Biotechnologies 71(2) / 2014, 297-298 (2014)

[13] Matiuți, M., Huțu, I., Matiuți C., Morariu F., Bioeconomic solutions for preserving the local breeds in the Banat Euroregion, USAM V Iasi, Lucrări știinţifice 59/3, 314-319 (2016)

[14] Denis, B., Eglin, J. E., Les races locales d'animaux domestiques: un element peu connu du patrimoine, Rev. de la Societe d'Ethnozootechnie Toul (France), Etnozootechnie no. 94, 13-18 (2013)

[15] Popescu, V., Evolutia asezarilor rurale din Banat, Ed. WALDPRESS Timisoara (2003)

[16] Mathias, E. (coordonator), Adding value to livestock diversity. Marketing to promote local breeds and improve livelihoods, FAO Rome (2010)

[17] Avon, L., Races francaises a faibles effectifs, Institut de l'Elevage Paris (2009)

[18] Matiuți, M., Bogdan A. T., Gaspardy, A.,
Diaconescu, D., An innovative application of the bioeconomic strategies and action plans elaborated by the European Union for 2030 at a crossborder level in the Danubian Euroregions, JEPE 16/1, 280-291(2015)

[19] Matiuți, M., Huțu, I., Diaconescu, D., Sonea, C., Rural Pole for Competitivity: a Pilot Project for Circular Economy, JEPE 18/2, 802-808 (2017)

[20] Vintila, T., Negrea, A., Barbu, H., Sumalan, R., Kovacs, K., Metal Distribution in the Process of Lignocellulosic Ethanol Production from Heavy Metal Contaminated Sorghum Biomass, Journal of Chemical Technology \& Biotechnology 91, 6/2016, 1607-1614(2016)

[21] Vintila, T., Gherman V. D., Popa, N., Popescu, D., Buzatu, C., Motoc, M., Influence of Enzymatic Cocktails on Conversion of Agricultural Lignocellulose to Fermentable Sugars, Revista de Chimie, 68/2, 373-377 (2017)

[22] Matiuți, M., Matiuți, C. L., Resursele genetice animale din spaţiul carpato dunărean. Etnozootehnie, Ed. Tempus, Timișoara, ISBN 978-973-1958-20-0, 363 pages (2012) 